\title{
Left ventricular clot in a patient with stroke
}

\author{
Ali Raza Rajani, ${ }^{1}$ Kosar Hussain, ${ }^{2}$ Fahad Omar Baslaib, ${ }^{1}$ Pushpa Rani Govindaswamy ${ }^{1}$ \\ ${ }^{1}$ Department of Cardiology, Rashid Hospital, Dubai Health Authority, Dubai, United Arab Emirates \\ ${ }^{2}$ Department of Internal Medicine, Rashid Hospital, Dubai Health Authority, Dubai, United Arab Emirates
}

Correspondence to Dr Ali Raza Rajani, arrajani@dha.gov.ae

\section{DESCRIPTION}

A 61-year-old man presented with sudden onset of leftsided weakness and slurred speech that had started $1 \mathrm{~h}$ prior to presentation. He was a non-smoker and his medical history included hypertension and ischaemic heart disease for which he was receiving treatment. On examination he had dysarthria, dense left-sided hemiplegia and upper motor neurone lesion of the facial nerve. His initial brain CT was reported as normal. Since he had presented within the window period for thrombolysis, he was thrombolysed with tPA (tissue plasminogen activator). Post-thrombolysis his neurological status improved considerably. The ECG demonstrated left bundle branch block, while the cardiac enzymes were negative. Subsequently cardiac echocardiography was done which showed dilated left ventricle with an ejection fraction of $20 \%$. The apex, septum, apico-lateral and inferior walls were akinetic. A large friable, mobile thrombus measuring $4.17 \times 1.47 \mathrm{~cm}$ (figure 1) was attached to the apex and protruding into the left ventricle (video 1). A diagnosis of left ventricular thrombus secondary to dilated ischaemic cardiopathy was made. Anticoagulation was initiated while he was in hospital. At discharge he was advised to continue warfarin, aspirin, statin and his usual antihypertensive medication.

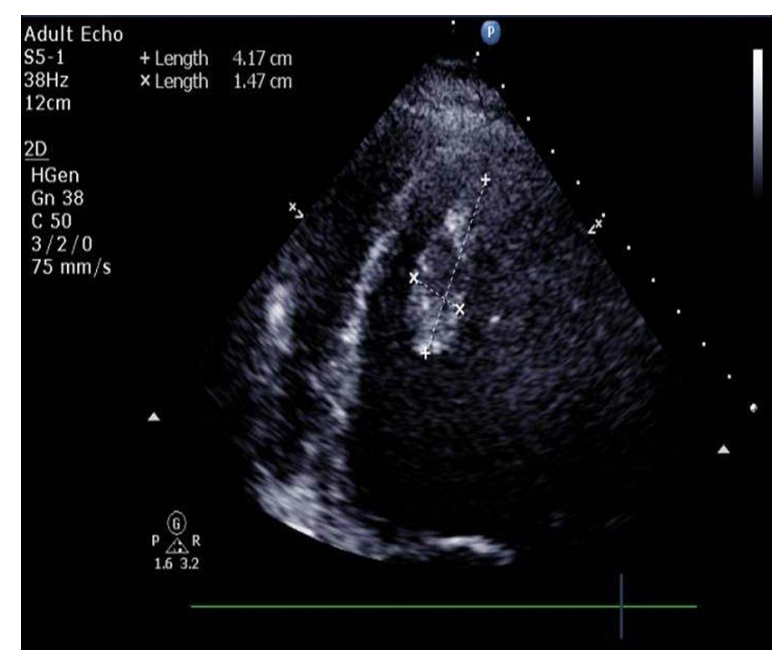

Figure 1 Apical four-chamber view of echocardiogram showing left ventricular clot that measured $4.17 \times 1.47 \mathrm{~cm}$ in dimension.

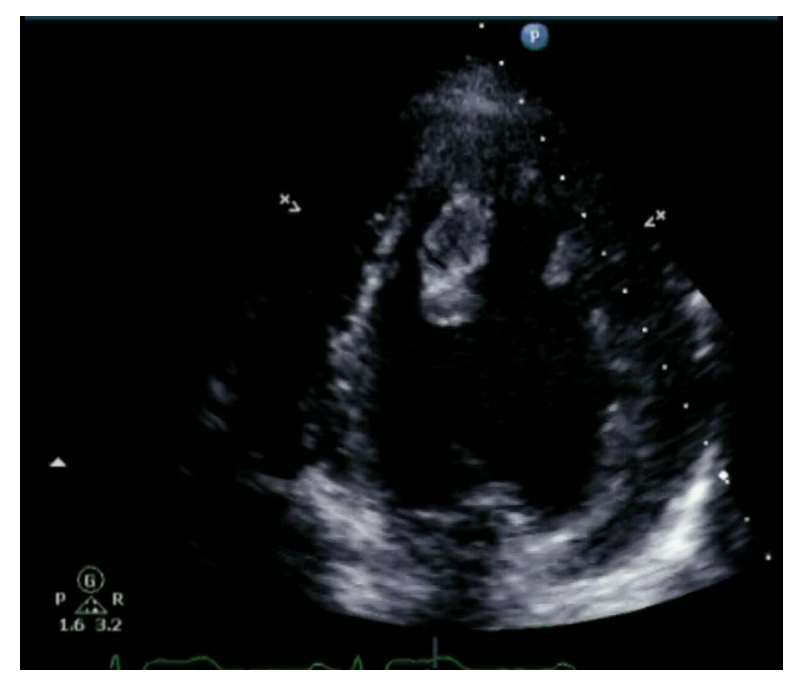

Video 1 Apical four-chamber view of echocardiogram showing a large, mobile clot in the left ventricle.

The detection of left ventricular clot in cases of embolic stroke carries prognostic and therapeutic importance. Our case demonstrates the classic echocardiographic features of left ventricular clot that increase its propensity for embolisation. These features include the presence of a mobile and protruding thrombus. ${ }^{1}$ Patients with documented left ventricular clot are recommended to receive oral anticoagulants (with target international normalised ratio of 2.5) for secondary prevention of further thromboembolic episodes. ${ }^{2}$

\section{Learning points}

An echocardiographic evaluation is necessary for all patients with ischaemic stroke.

- Patients with documented left ventricular clot benefit from anticoagulation to prevent thromboembolic episodes.

Competing interests None.

Patient consent Obtained. 


\section{BMJ Case Reports}

\section{REFERENCES}

1. Wilensky RL, Jung SC. Thromboembolism in patients with decreased left ventricular function: incidence, risk, and treatment. J Cardiovasc Risk 1995;2:91-6.
2. Furie KL, Kasner SE, Adams RJ, et al. Guidelines for the prevention of stroke in patients with stroke or transient ischemic attack: a guideline for healthcare professionals from the American Heart Association/American Stroke Association. Stroke 2011;42:227-76.

Copyright 2012 BMJ Publishing Group. All rights reserved. For permission to reuse any of this content visit http://group.bmj.com/group/rights-licensing/permissions.

BMJ Case Report Fellows may re-use this article for personal use and teaching without any further permission.

Please cite this article as follows (you will need to access the article online to obtain the date of publication).

Rajani AR, Hussain K, Baslaib FO, Govindaswamy PR. Left ventricular clot in a patient with stroke. BMJ Case Reports 2012;10.1136/bcr-2012-007251, Published XXX

Become a Fellow of BMJ Case Reports today and you can:

- Submit as many cases as you like

- Enjoy fast sympathetic peer review and rapid publication of accepted articles

- Access all the published articles

- Re-use any of the published material for personal use and teaching without further permission

For information on Institutional Fellowships contact consortiasales@bmjgroup.com

Visit casereports.bmj.com for more articles like this and to become a Fellow 